\title{
Geographical distribution and anatomical features of Malus domestica (Suckow) Borkh. (Malus sieversii M. Roem.) in Ustyurt of Uzbekistan
}

\author{
M. Tajetdinova Dilarom ${ }^{\star}$ and B. Berdibaeva Dilfuza* \\ Institute of Botany of the Academy of Sciences, Tashkent Botanical Garden at the Institute of Botany, Academy of Sciences of the Republic of \\ Uzbekistan \\ *Laboratory of Introduction of Medicinal and Ornamental Plants in Tashkent Botanical Garden, Institute of Botany of the Academy of
} Sciences, Tashkent, Uzbekistan

\section{Article Info}

\section{Article history}

Received 23 August 2021

Revised 9 October 2021

Accepted 10 October 2021

Published Online 30 December 2021

\section{Keywords}

Malus domestica

Ustyurt

Arg GIS

Sclerenchyma

Phloem

\begin{abstract}
The scientific research was conducted to study the modern flora of Ustyurt, one of the arid regions of Central Asia (Uzbekistan). In the course of the study, the place of growth of the species, Malus domestica (Suckow) Borkh. (Malus sieversii M. Roem.) was identified. The samples of herbarium were brought and transferred to the TASH. The geographical distribution of $M$. domestica region of Ustyurt was Arg GIS map and analyzed. The anatomical structure of the petiole of $M$. domestica was analyzed. For this species, diagnostic indicators as, shape of petiole, epidermis cells, degree of omission, sclerenchyma ring often interrupted by small groups above phloem bundle. Sclerenchyma group is more multilayered and crystal type is drusy. The results obtained can be used in the description of anatomical studies in the subfamily, Rosoideae.
\end{abstract}

\section{Introduction}

The Ustyurt District is located in the West-South of the Aral Sea region on the territory of Karakalpakstan and in the arid (desert) zone of the Republic of Uzbekistan. Nowadays, the increasing of economic activity in the arid zone of Uzbekistan, especially development of the gas and oil producing industry in the Ustyurt, caused to the transformation of flora, vegetation and landscapes of this region. The vegetation of this territory has an economic value as pastures for livestock, mainly for Astrakhan sheep.

The flora of Ustyurt accounts 724 species of vascular plants including a large number of endemic, rare and cultural plants species (Saribaev, 1994). A special place in the flora of Ustyurt is occupied by wild relatives of cultivated plants. Their gene pool should be widely used in hybridization to create new cultivars.

Malus domestica (Suckow) Borkh. (Malus sieversii M. Roem.) is considered to be founder of many modern sorts of cultivated apple-trees (Coart et al., 2006). According to literary data on DNA analysis, Sievers apple tree along with crab apple made an essential contribution to the origin of cultivated apple (Velasco et al., 2010). Nowadays, it is endangered due to man impact.

The main geographical center of origin of cultivated apple trees are the mountain systems of Asia-Kopetdag, Alai Range, Zailiysky and Dzhungarsky Alatau, Fergana and Zeravshansky ranges,

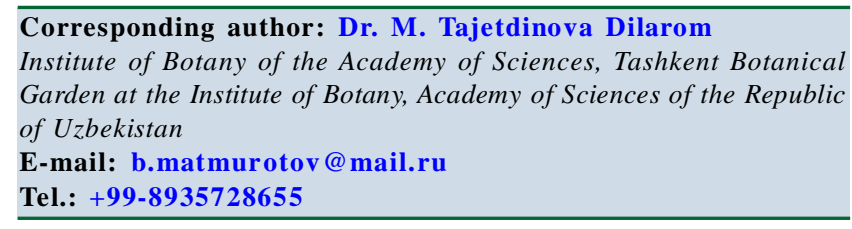

Copyright $\odot 2021$ Ukaaz Publications. All rights reserved.

Email: ukaaz@yahoo.com; Website: www.ukaazpublications.com
Talassky Alatau, Tien Shan. This geographical region concentrates the main species diversity of wild apple trees of more ancient origin than other types of apple trees (Pratov, 1976).

\section{Materials and Methods}

Our field research was conducted in 2013-2015 in the Ustyurt desert regions of Uzbekistan by traditional methods. Where necessary, the patterns were redefined using Flora of Uzbekistan (Kudryashev, 1955) and Conspectus Florae Asia Mediae (Pratov, 1976). The accepted scientific names of taxa are used by electronic resources (http://www.plantsoftheworldonline.org., https:// beta.ipni.org/). The plant coordinates were imported into Arg GIS 10.0 and converted to a point map layer. The WGS84 Geographic coordinate system was used as the reference point. Digitization of herbarium samples was carried out by scanning using a Herbscan TM 224 + Epson Expression 10000 XL.

We made research on petiole of $M$. domestica (Suckow) Borkh. there to cross section through bottom of petiole with blade and core of elder berry was made. Sections were stained by safranin, was preserved by spirit of $70 \%$ concentration and was put into balsam. Research was made on light microscope Biolam P-15. Measurements were taken by helical eyeglass micrometer MOB-15 (Trankovskiy, 1979). To describe was used terminology, applied in modern anatomical literature (terminology used in modern anatomical literature.).

This study has been carried out within the framework of the State Research projects of the Institute of the Botany of the Academy of Sciences of the Republic of Uzbekistan "Botany geographical regionalization and the creation of a database of plant diversity of Uzbekistan Part II Turan province" and "Systematics of vascular plants of the natural flora of Uzbekistan". 


\section{Results}

During the floristic study (2013-2014), we found one specimen of Malus domestica (Suckow) Borkh. (N44036.26.6 E058 16.31.1), the part of Karakalpakstan (Uzbekistan) of the Ustyurt (Tajetdinova, 2015).

Malus domestica (Suckow) Borkh. in Theor. Prakt. Handb. Forstbot. 2: 1272 (1803), nom. cons.

Specimen seen Uzbekistan (TASH): East chink of the Ustyurt between Ustyurt and the Aral Sea.06 V 2014, D.M. Tajetdinova, Det.: U. Pratov (Figures 1, 2).

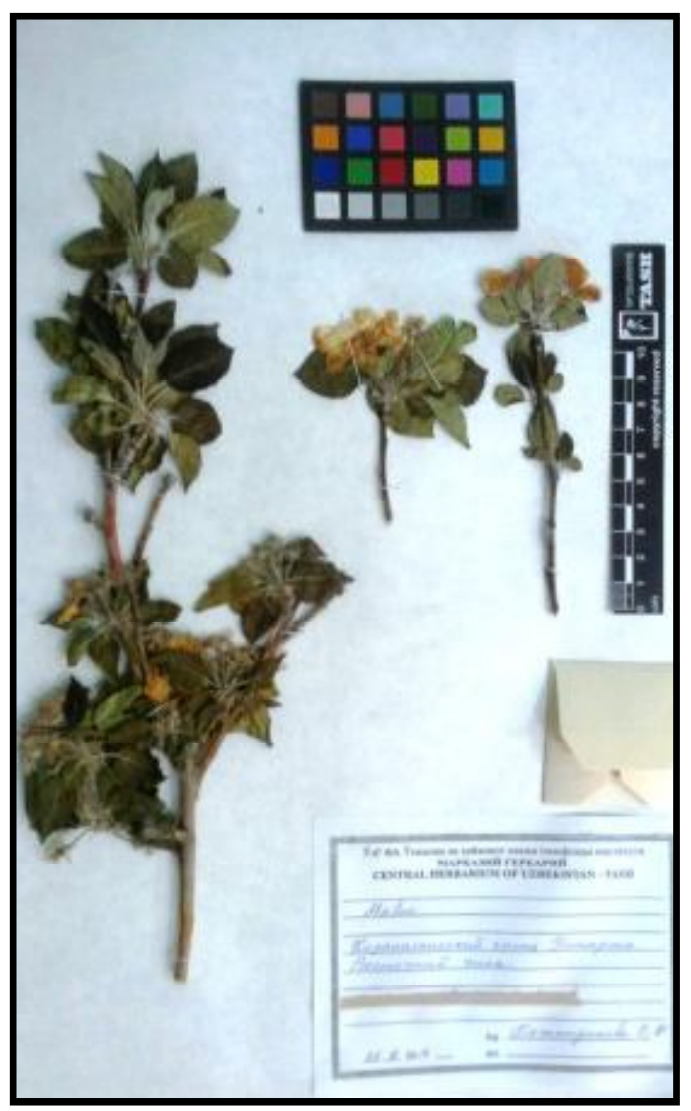

Figure 1: Malus domestica (Suckow) Borkh. (M. sieversii M. Roem.) (TASH).

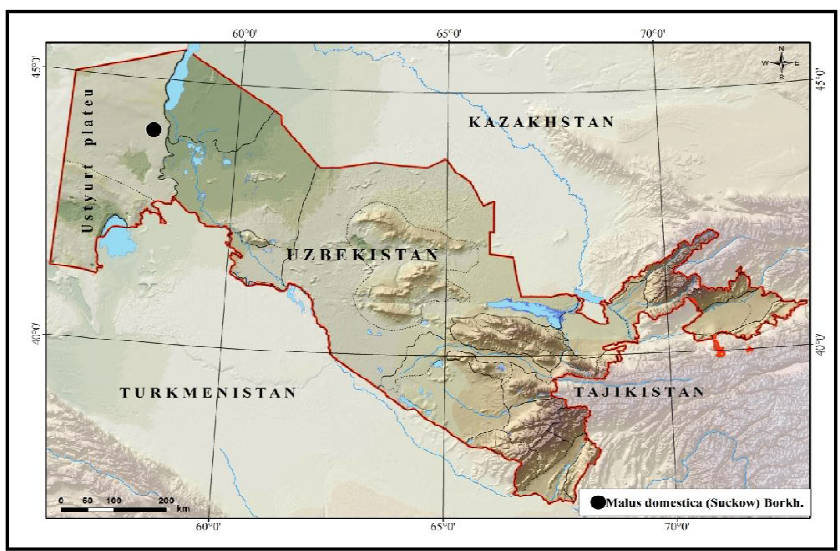

Figure 2: Distribution of the Malus domestica (Suckow) Borkh. the Ustyurt.
Surface of petiole is delicately costate. Omission is average, has minor quantity of fuzz 13, $9 \pm 1,4$ (Table 1 ).

Table 1: Anatomical features of petiole Malus domestica on cross section

\begin{tabular}{|c|l|r|}
\hline No. & \multicolumn{1}{|c|}{ Features } & \multicolumn{1}{c|}{ um } \\
\hline 1 & Diameter of petiole & $837,2 \pm 3,2$ \\
2 & Number of fuzzes & $13,9 \pm 1,4$ \\
3 & The length of fuzz & $98,8 \pm 2,2$ \\
4 & Thickness of epidermal cells & $11,9 \pm 0,3$ \\
5 & Thickness of exterior walls of epidermal & $5,1 \pm 0,1$ \\
& cells & $56,0 \pm 0,5$ \\
6 & Thickness of collenchyma cells & $271,6 \pm 1,4$ \\
7 & Thickness of cortex parenchyma & $21,4 \pm 1,1$ \\
8 & Diameter of druse & $71,9 \pm 3,3$ \\
9 & Thickness of sclerenchyma in a bunch & $3,9 \pm 0,1$ \\
10 & Number of sclerenchyma cells in tangential & \\
& direction & \\
\hline
\end{tabular}

From the exterior side, petiole is covered by single-layered epidermis, and epidermal cells are large 11,9 $\pm 0,3 \mathrm{um}$. The exterior wall of epidermal cells is covered by cuticle and thickening of exterior membrane $5,1 \pm 0,1$ um is observed. On cross-section form of cell is rounded-square within convex exterior shell. Fuzz are monocellular, clothing and the length reaches 98,8 $\pm 2,2 \mathrm{um}$. Below is located collenchyma. It is of the angular type, in some places lamellar, the tissue is single layered, but in the ribs of the stem, the number of layers of the collenchyma increases to 2-3. The shape of the collenchyma cells is round-square, their size is more than 56.0 $\pm 0.5 \mathrm{um}$. Under the collenchyma, the cells of the cortex parenchyma are located. This tissue is composed of oval cells elongated in the tangential direction. Large-tissue fabric is $271.6 \pm 1.4 \mathrm{um}$. Two layers lying under the collenchyma consist of thin-walled cells and contain chloroplasts. The inner 2-3 layers are located near the bunches, having cells with thickened shells. Calcium oxalate crystals are found in the cells of the parenchyma. They have the appearance of druse. Druse size is more than $21.4 \pm 1.1 \mathrm{um}$. In the cells of the parenchyma, located near the beams, crystals were not detected. The petiole conductive system is represented by collateral conductive bunches located in the middle of the slice. One bunch is large, elongated in the tangential direction. Mechanical tissue reinforcing conductive bunches, sclerenchyma. It is in the form of "caps" located above the phloem. The lining of its cells is lignified. In the bundle, the sclerenchymatous tissue consists of 4-5 layers, the thickness of the sclerenchyma is $71.9 \pm 3.3 \mathrm{um}$, the mechanical tissue is intermittent, consists of groups of sclerenchymatous cells consisting of 3-4 rows of cells (in the tangent direction). Thus, in the structure of the petiole, $M$. sievérsii is characterized by the shape of the petiole, the character of the epidermis cells, the nature of the degree of omission, the sclerenchymatous ring is often interrupted into small groups above the bunch phloem, the sclerenchyma group is more multilined, the nature of one bunch, the type of crystals is druse (Figure 3). 


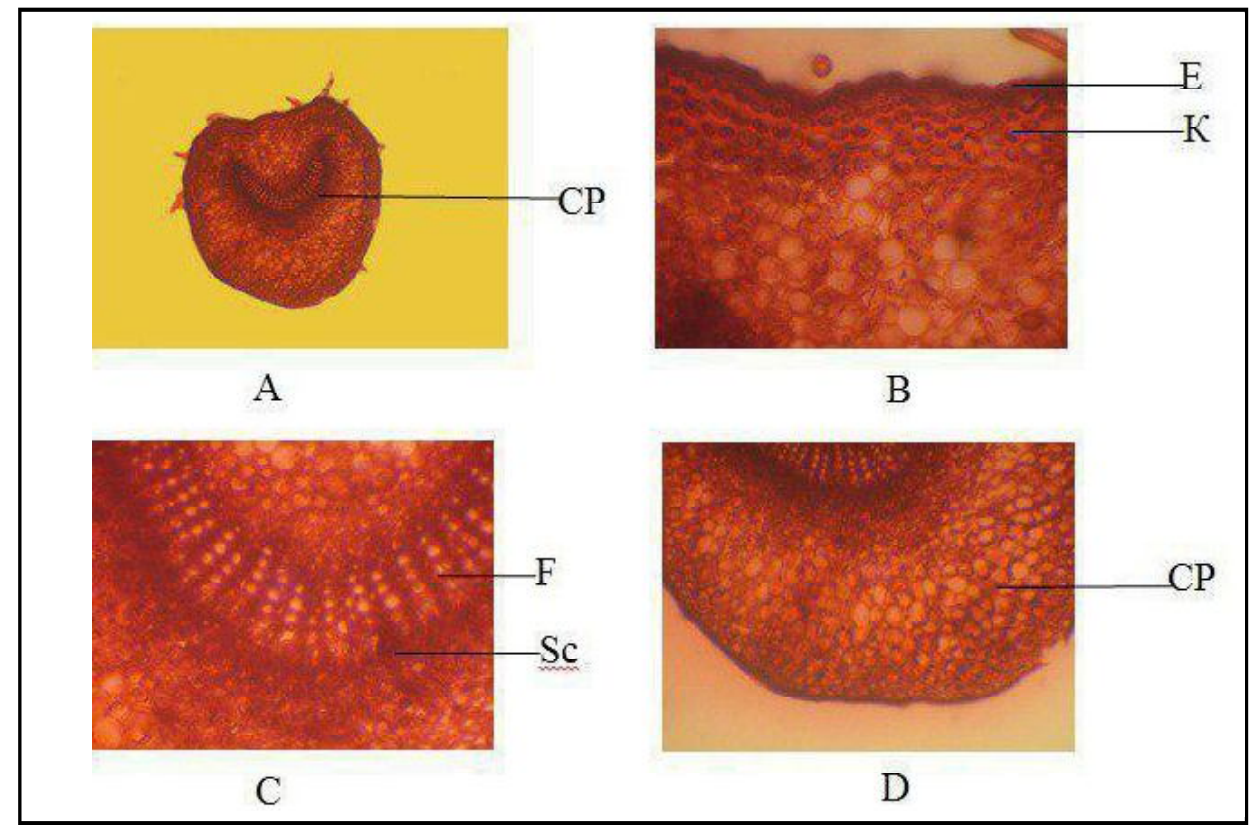

Pattern: Over all view of cross section of petiole, Malus domestica (̇̀) and details (B-C-D) of investigated sort: CB-conducting bundle, E-epidermis, $\hat{\mathbf{E}}$-collenchyma, F-phloem, Scsclerenchyma, CP-cortex parenchyma tissue.

Figure 3: Overall view of cross section of petiole Malus domestica (Suckow) Borkh.

\section{Discussion}

The main habitats of $M$. domestica are in the mountainous regions of Uzbekistan. The new area of this plant in Ustyurt is of great interest for understanding the history of the formation of the flora of Ustyurt.

The during the Tertiary period after the Tethys Sea began to retreat from Central Asia to the East-West, dehydrated tall plants became common. Among them, the ancestors of the M. domestica, we collected probably grew up. It can also be said that these species have survived over time as relics in chink-like locations where conditions have changed (especially due to the prevalence of drought).

Despite the fact that the Ustyurt region is a typical Turanian desert, various theoretical and practical conclusions can be drawn from the discovery of the species $M$. domestica during the expeditions:

- There may be remains of cultivated plants that grew in past geological periods, and then decreased in size as a result of various natural changes;

- Seeds can be adapted to growing and shedding conditions through a variety of factors, including animals, birds and humans.

In Kazakhstan, under the conditions of the main Botanical Garden of Almaty was studied the chemical and technological characteristics of new varieties-clones of Sievers apple. Biochemical and technological indicators of fruit quality of Sievers apple clone varieties were studied and the most valuable varieties for processing and their use in breeding were highlighted. Biochemical and technological indicators of fruit quality of Sievers apple clone varieties were studied and the most valuable varieties for processing and their use in breeding were highlighted. Biochemical and technological indicators of fruit quality of Sievers apple clone varieties were studied and the most valuable varieties for processing and their use in breeding were highlighted.The study revealed varieties with high content of nutrients and biologically active substances, which can serve as a valuable source for breeding and processing. Besides, the anatomical structure of the cuttings and radial parenchyma of the Sievers apple tree has been studied and characterized in order to multiply endemic fruit plants (https:// znanio.ru/media/study-of-histostructure-of-ray-parenchymarooting-ability-of-sievers-apple-malus-sieversii-endemic-speciesin-green-cutting-2632200).

The breeding and economic value of local varieties of folk selection and forms of Sievers apple in different ecological and geographical zones of Tajikistan has been studied. The morphological features have been studied and the differences of wild forms of Sievers apple tree by anatomical structure of the leaf have been revealed, on the basis of which the group of drought-resistant forms has been selected. The morphology of a variety of apples in the Kashmir Valley has been studied. Their different morphological characteristics from different habitats were studied. Differences in length and width of leaf plate, petiole length, fruit length, number of seeds per fruit were shown (http://plantarchives.org/17-2/1071-1077\%20(3899)).

\section{Conclusion}

The results of the study showed that Malus domestica (Suckow) Borkh. (Malus sieversii M.Roem.) growing in the mountains of 
Central Asia is found in the deserts of Ustyurt. This is important and makes it possible to use their gene pool in agriculture to create new varieties of cultivated plants.

The study of the petiole of $M$. sieversii showed that the studied species in the anatomical structure have many characteristic features that can be regarded as diagnostic. The results obtained can be used in the description of anatomical studies in the Rosoideae subfamily.

In this regard, it is necessary not only to strengthen the protection of their natural habitats, but also, considering their value as a gene pool, to introduce them into culture.

Thus, a serious question arises of the protection of flora and vegetation of the Ustyurt plateau, as well as the development of measures for the preservation of certain species.

\section{Conflict of interest}

The authors declare no conflicts of interest relevant to this article.

\section{References}

Coart, E.; Van Glabeke, S.; De Loose, M.; Larsen, A.S. and Roldán-Ruiz, I.(2006). Chloroplast diversity in the genus Malus: New insights into the relationship between the European wild apple (Malus sylvestris (L.) Mill.) and the domesticated apple (Malus domestica Borkh.). Molecular Ecology, 15(8):2171-2182.DOI: 10.1111/j.1365-294X.2006.02924.x.
Dzhangaliev, A.D. (2007). Unique and global importance of the gene pool of the apple forests of Kazakhstan. Reports of the National Academy of Sciences of the Republic of Kazakhstan, 5:41-47 (In Russian).

IPNI (2019). International Plant Names. Index.https://beta.ipni.org/

Kudryashev, S.N. (1955). Málus Mill.In: Flora of Uzbekistan. Tashkent, 3:278-290 (In Russian).

POWO (2019). Plants of the World Online. Facilitated by the Royal Botanic Gardens, Kew. http://www.plantsoftheworldon line.org.

Pratov, U.P. (1976). Málus Mill.In: Conspectus Florae Asiae Mediae. Tashkent. 5:146-212 (In Russian).

Saribaev, B. (1994). Flora and vegetation of plateau Ustyurt and prospects of their use. Doctoral thesis, Tashkent, pp:48 (In Russian).

Tajetdinova, D.M. (2015). About new locations of wild relatives of cultivated plants in ustyurt. Reports of the Academy of Sciences Republic of Uzbekistan. Tashkent, 4:66-68 (In Russian).

Trankovskiy, D.A. (1979). Practical work on anatomy of plants. High School. İoscow, pp:221.

Velasco, R., Zharkikh, A. and Affourtit, J. (2010). The genome of the domesticated apple (Malus $\times$ domestica Borkh.). Nature Genetics., 42(10):833. DOI:10.1038/ng654 